\title{
Effect of quality of sperm chromatin structure on in -vitro production of cattle embryos*
}

\begin{abstract}
Bull effect on results of in vitro embryo production has been well documented. The aim of the present study was to find the relationship between quality of bull sperm chromatin and its effect on in vitro embryo production. Bovine in vitro matured oocytes were fertilized in vitro using capacitated spermatozoa (freshly ejaculated or frozen-thawed) of 12 bulls. Semen was simultaneously processed according to the sperm chromatin structure assay (SCSA) method and was analysed by flow cytometry. At least 3 replications of IVP with the same semen sample were done. The percentage of spermatozoa with abnormal chromatin ranged from $0.4 \%$ to $23.8 \%$. All bulls used for the experiment were divided into three groups showing minimal $(0.82 \% \pm 6.82 \%)$, low $(1.70 \% \pm 15.82 \%)$ and high $(18.16 \% \pm 53.59 \%)$ percentages of spermatozoa with abnormal chromatin structure. Both cleavage rates and embryo development to the blastocyst stage were correlated significantly with sperm chromatin abnormalities and resulted in 23.1, 17.7 and $12.2 \%$ of blastocysts respectively for sperm with minimal, low and high percentages of chromatin abnormalities. The SCSA method may be used as a practical indicator of suitability of bull ejaculate for IVP purposes.
\end{abstract}

Key Words: cattle, in-vitro-embryo-production, flow cytometry, sperm chromatin

\section{Zusammenfassung}

Titel der Arbeit: Der Effekt der Qualität der Spermachromatinstruktur auf die In-vitro-Produktion von Embryonen beim Rind

Der Einfluss von Bullen auf die Ergebnisse der In-vitro-Produktion von Embryonen ist ausreichend publiziert. Das Ziel der Untersuchungen war es Zusammenhänge zwischen der Chromatinqualität von Bullensperma und deren Effekt auf die IVP Embryonen zu untersuchen.

In vitro gereifte Rindereizellen wurden mit kapazitierten Spermien (frisch ejakuliert oder kryokonserviert) von 12 Bullen in vitro befruchtet. Die Spermaproben wurden hinsichtlich ihrer Chromatinstruktur mit der SCSAMethode untersucht.

Alle 12 Bullen wurden auf drei Gruppen aufgeteilt: Minimaler Anteil an defektem Chromatin $(0,82 \pm 6,82 \%)$, geringer (1,70 $\pm 15,82 \%)$ und hoher Anteil (18,16 $\pm 53,59 \%)$. Sowohl die Furchungsrate als auch der Anteil an Blastozysten (23,1, 17,7 und 12,2 \% für minimale, geringe und hohe Anteile an Anomalien) korrelierte signifikant mit den Spermadefekten. Die Ergebnisse deuten darauf hin, dass die SCSA-Methode als Indikator für die Eignung von Bullenejakulaten für die IVP genutzt werden kann.

Schlüsselwörter: Rind, In-vitro-Embryonen-Produktion, Durchflusszylometrie, Spermachromatin

\section{Introduction}

Commonly used methods that evaluate semen quality microscopically are limited in reliability. Routinely determined parameters include semen concentration, percentage of motile spermatozoa, and type of motility. Microscopic analysis, which increasingly uses computers (CASA - Computer Assisted Sperm Analysis), and the survival rate of spermatozoa only indicate those ejaculates that are completely unsuitable for freezing and insemination. Moreover, microscopic analysis of sperm quality does not indicate its usefulness for in vitro fertilization (IVF).

\footnotetext{
* Research was supported by the State Committee for Scientific Research (KBN) as a project 3PO6D 04423
} 
Recently, flow cytometry has been used successfully to evaluate mammalian spermatozoa. Flow cytometry can be used to analyse many structures and functional characteristics of spermatozoa, such as cell membrane integrity (GARNER et al., 1992,1994; GRAHAM et al., 1990; RODRIGUEZ-MARTINEZ, 2001), mitochondrial activity (GRAHAM et al., 1990), changes in spermatozoa surface during capacitation (ASHWORTH et al., 1995), acrosome damage (FENICHEL et al., 1989; GRAHAM et al., 1990; UHLER et al., 1993; GILLES et al., 2001), and chromatin structure and its "maturation" during spermatogenesis (KARABINUS et al., 1990, 1991; SAILER et al., 1996).

Sperm chromatin structure assay (SCSA) is based on the assumption that structurally abnormal sperm chromatin is more susceptible to acid or heat denaturation (EVENSON, 1990). The SCSA method takes advantage of the metachromatic properties of acridine orange. This dye fluoresces in the green band when combined with RNA and denatured DNA (DARZYNKIEWICZ, 1990). After mild denaturation of chromatin through decreased $\mathrm{pH}$, the fluorescence of spermatozoa with structurally abnormal chromatin is strengthened in the red band. A significant relationship has been found between fertility of bulls qualified for AI and the percentage of spermatozoa with high susceptibility to chromatin denaturation (BOCHENEK et al., 2001).

Results of IVF in cattle indicate that individual bulls differ in their contribution to both fertilization and embryonic development (EYESTONE and FIRST, 1989; HILLERY et al., 1990; BARANDI et al., 1993; KĄTSKA and RYŃSKA, 1994; GALLI et al., 2003). Some bulls perform better than others and a small proportion $(<5 \%)$ performs really very poor (GALLI et al., 2003). However, reasons for these differences have not been recognized. From a practical point of view, establishing methods that allow the use of IVP semen from unselected bulls with a satisfactory efficiency seems to be an unsolved problem.

In this respect, the present study was undertaken to examine the relationship between quality of bull sperm chromatin and its effect on in vitro fertilizability and developmental capacity of in vitro matured oocytes.

\section{Material and Methods}

In vitro maturation. Bovine ovaries were collected at the local abattoir and were transported to the laboratory at 28 to $30^{\circ} \mathrm{C}$ within 2 to $3 \mathrm{~h}$ of slaughter. The ovaries were washed three times in warm PBS supplemented with $0.075 \mathrm{~g}$ kanamycin $1^{-1}$. Cumulus-oocyte complexes (COCs) were freed from ovaries following the isolation and subsequent rupture of vesicular follicles 2 to $8 \mathrm{~mm}$ in diameter in manipulation medium (KĄTSKA et al., 1996). The manipulation medium consists of TCM-199, Earle's salt with glutamine and without sodium bicarbonate, buffered with $25 \mathrm{mM}$ Hepes and supplemented with 10\% fetal calf serum (FCS). Oocytes with compact cumulus and evenly granulated cytoplasm were cultured in $2 \mathrm{ml}$ of TCM-199 (Earle's salt, buffered with sodium bicarbonate, $\mathrm{pH} 7.4$ ) supplemented with $20 \%$ estrous cow serum (ECS, heat inactivated) and an additional 3 to $5 \times 10^{6}$ granulosa cells $\mathrm{ml}^{-1}$. Oocytes were cultured for 22 to $23 \mathrm{~h}$ at $38.5^{\circ} \mathrm{C}$ in humidified atmosphere (KATTSKA et al., 1996).

In vitro fertilization. Mature COCs were washed and partially deprived of expanded cumulus cells before being transferred in groups up to 10 into $40 \mu$ fertilization drops 
of TALP- IVF (PARRISH et al., 1988) containing a PHE mixture consisting of penicillamine (20 $\mu \mathrm{M}$; Sigma), hypotaurine $(10 \mu \mathrm{M}$; Sigma) and epinephrine $(1 \mu \mathrm{M}$; Sigma) and $10 \mu \mathrm{g}$ of heparin-sodium salt/ml of TALP-IVF medium.

Frozen semen of 12 bulls obtained from Polish animal breeding stations was used for the experiment. All semen samples were characterized by similar morphological parameters (motility after thawing above $50 \%$, similar survival time and morphology of spermatozoa). Semen was simultaneously used for IVF and tested for the quality of chromatin.

Semen was thawed in a water bath at $37^{\circ} \mathrm{C}$ and expelled from the straw into $1 \mathrm{ml}$ calcium ion-free TALP medium (PARRISH at al., 1988) at $37^{\circ} \mathrm{C}$. To remove the extender the samples were centrifuged at $300 \times \mathrm{G}$ for $10 \mathrm{~min}$. After extracting the supernatant, motile spermatozoa were obtained by centrifugation of sperm suspension on a discontinuous Percoll (Pharmacia, Uppsala, Sweden) density gradient (1 $\mathrm{ml} 45 \%$ Percoll over $1 \mathrm{ml} \mathrm{90 \%} \mathrm{Percoll)} \mathrm{for} 30 \mathrm{~min}$ at $300 \mathrm{x} \mathrm{g}$ at room temperature. Viable spermatozoa, collected at the bottom of the $90 \%$ fraction, were washed in calcium ionfree TALP medium and pellet by centrifugation at $100 \mathrm{x}$ g for $10 \mathrm{~min}$. Spermatozoa were counted in a haemocytometer and diluted up to approx. 3-5 x 10 $\mathrm{sperm} / \mathrm{ml}$ in the calcium ion-free TALP medium. This suspension was added to fertilization drops to give the final concentration of $1-2 \times 10^{6}$ spermatozoa $/ \mathrm{ml}$. Gametes were incubated together for 20 to $22 \mathrm{~h}$ at $39^{\circ} \mathrm{C}$ under $5 \% \mathrm{CO}_{2}$ in air.

Sperm chromatin structure assay (SCSA). For chromatin denaturation and staining we followed the two-stage SCSA protocol (BOCHENEK et al., 2001). We added $0.4 \mathrm{ml}$ of solution A (consisting of $0.1 \mathrm{ml}$ of Triton X-100, $8.0 \mathrm{ml}$ of $1.0 \mathrm{~N} \mathrm{HCl}, 0.877 \mathrm{~g} \mathrm{NaCl}$ diluted in $2 \mathrm{x}$ distilled $\mathrm{H}_{2} \mathrm{O}$ to final volume of $100 \mathrm{ml}$ ) to $0.2 \mathrm{ml}$ of sperm suspension containing $1 \times 10^{6}$ spermatozoa $/ \mathrm{ml}$ of PBS medium. After $30 \mathrm{sec}, 1.2 \mathrm{ml}$ of solution B (containing in $100 \mathrm{ml}$ of citric-phosphate buffer $0.877 \mathrm{~g} \mathrm{NaCl}, 0.034 \mathrm{~g}$ EDTA-Na 2 and $0.6 \mathrm{ml}$ of acridine orange solution with concentration of $1 \mathrm{mg} / \mathrm{ml}$ ) was added and after additional $3 \mathrm{~min}$ we proceeded to the cytometric analysis. Staining procedure and flow-cytometrical examination were carried out at $4^{\circ} \mathrm{C}$.

A Coulter Epics Elite flow cytometer was used. Acridine orange was excited at 488 $\mathrm{nm}$ and $35 \mathrm{~mW}$ laser beam. Fluorescence was read out through 550DL and 525BP filters in the green band and through a 675BP filter in the red band. To standardize all analyses, the same frozen/thawed ejaculate was used to calibrate the cytometer. Five thousand spermatozoa were measured for each semen sample (BOCHENEK et al., 2001).

Embryo culture. After 22 to $24 \mathrm{~h}$ of gametes incubation, the oocytes were washed, freed of attached cells and transferred into $40 \mu \mathrm{l}$ drops of $\mathrm{B}_{2}$ medium (C.C.D., Paris, France) under mineral oil for 20 to $24 \mathrm{~h}$ ( 40 to $44 \mathrm{~h}$ post insemination). Then, uncleaved ova were discarded and embryos were placed in co-culture with Vero cells in $500 \mu \mathrm{l}$ of $\mathrm{B}_{2}$ medium into 4-well dish for a further 6 to 8 days culture, i.e. up to the hatched blastocyst stage (KĄTSKA et al., 1998). Medium in co-culture was partially changed every $48 \mathrm{~h}$.

\section{Results}

The results of cytometric analysis of chromatin structure showed a large variation among ejaculates of different bulls. The $\mathrm{COMP}_{\alpha t}$ parameter reflecting the percent of 
spermatozoa with abnormal chromatin ranged from $0.37 \%$ (Fig. 1) to $23.83 \%$ (Fig. 2). The other parameter, $\mathrm{SD}_{\alpha \mathrm{t}}$, revealed a similar trend ranging from $6.27 \%$ to $76.50 \%$ (Table 1). When these sperm samples showing the differentiated quality of their chromatin were used for in vitro embryo production (IVP) results were highly differentiated and it was difficult to analyse them (Table 1). Therefore, on the basis of chromatin structure quality all bulls used for the experiment were divided into three groups showing minimal $(0.82 \%)$, low $(1.70 \%)$ and high $(18.16 \%)$ percentages of spermatozoa with abnormal chromatin structure (Table 2).

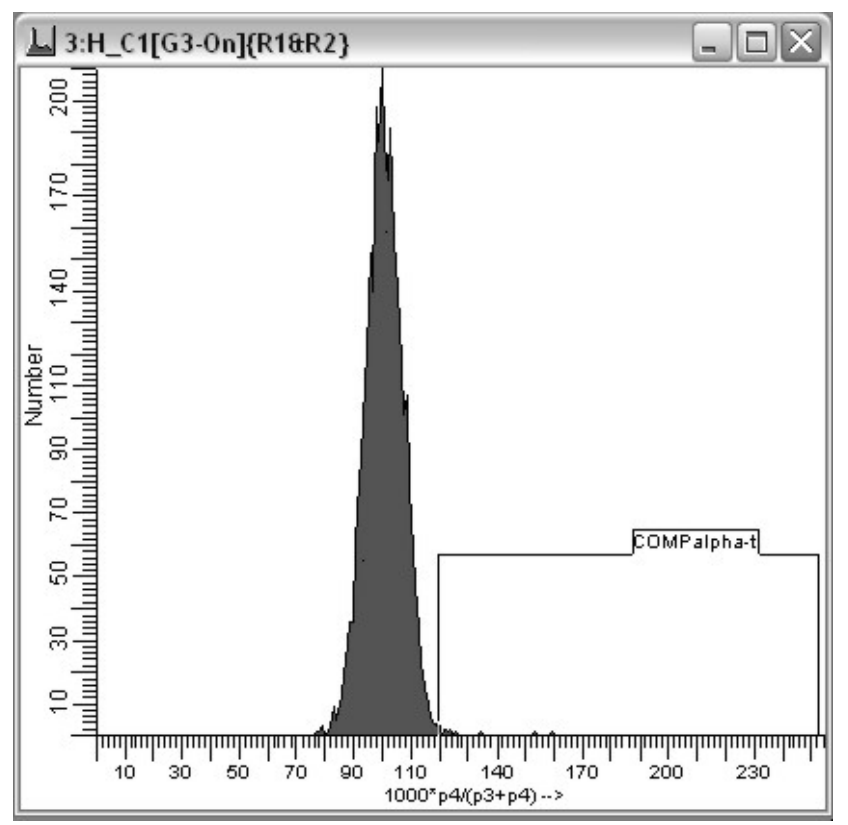

Fig. 1: Sperm chromatin structure assay (SCSA) showing minimal (0.37\%) percentage of spermatozoa with chromatin abnormality (COMPalpha-t) (Minimale Anteile (0,37\%) an Spermien mit Chromatinanomalien nach Verwendung von SCSA (COMPalpha-t))

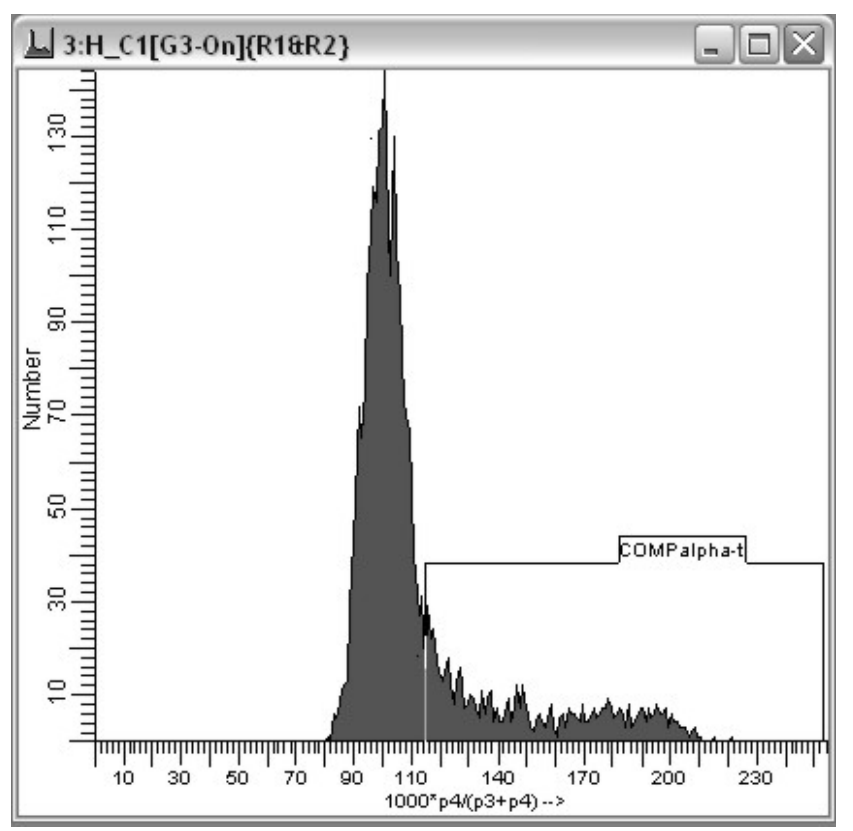

Fig. 2: Sperm chromatin structure assay (SCSA) showing high (23.83\%) percentage of spermatozoa with chromatin abnormality (COMPalpha-t) (Hohe Anteile $(23,83 \%)$ an Spermien mit Chromatinanomalien nach Verwendung von SCSA (COMPalpha-t)) 
Table 1

The quality of sperm chromatin and the developmental competence of bovine IVM oocytes fertilized with these sperm samples (Qualität von Spermachromatin und Entwicklungsfähigkeit von in vitro gereiften bovinen Oozyten befruchtet mit verschiedenen Spermaproben)

\begin{tabular}{cccccc}
\hline $\begin{array}{c}\text { No of } \\
\text { bull }\end{array}$ & $\begin{array}{c}\mathrm{COMP}_{\alpha \mathrm{t}}{ }^{1} \pm \\
\mathrm{SD}_{\alpha \mathrm{t}}^{2}\end{array}$ & $\begin{array}{c}\text { No of oocytes } \\
\text { (replic.) }\end{array}$ & $\begin{array}{c}\text { Cleaved embryos } \\
\text { No }(\%)\end{array}$ & \multicolumn{2}{c}{ No of blastocysts (\%) } \\
\hline 1 & $1.06 \pm 7.37$ & $355(6)$ & $300(84.5)$ & $102(28.7)$ & $47(46.1)$ \\
2 & $1.04 \pm 6.82$ & $664(12)$ & $544(82.0)$ & $130(19.6)$ & $31(23.8)$ \\
3 & $0.37 \pm 6.27$ & $131(4)$ & $116(88.5)$ & $34(29.3)$ & $17(50.0)$ \\
4 & $3.23 \pm 9.76$ & $139(5)$ & $66(47.5)$ & $15(22.7)$ & $7(46.7)$ \\
5 & $1.71 \pm 16.30$ & $129(4)$ & $82(63.6)$ & $23(17.8)$ & $17(73.9)$ \\
6 & $1.17 \pm 18.27$ & $191(6)$ & $140(73.3)$ & $36(18.8)$ & $19(52.8)$ \\
7 & $1.98 \pm 13.02$ & $117(4)$ & $80(68.4)$ & $14(12.0)$ & $6(42.9)$ \\
8 & $23.83 \pm 76.50$ & $238(7)$ & $131(55.0)$ & $24(10.1)$ & $10(41.7)$ \\
9 & $14.7 \pm 36.99$ & $142(5)$ & $46(32.4)$ & $13(9.1)$ & $9(69.2)$ \\
10 & $15.96 \pm 47.29$ & $121(4)$ & $80(66.1)$ & $24(19.8)$ & $14(58.3)$ \\
11 & $1.33 \pm 16.10$ & $92(3)$ & $78(84.8)$ & $24(26.1)$ & $13(54.2)$ \\
12 & $1.82 \pm 21.19$ & $105(3)$ & $81(77.1)$ & $25(23.8)$ & $14(56.0)$ \\
\hline
\end{tabular}

${ }^{1} \mathrm{COMP}_{\alpha \mathrm{t}}=\%$ of spermatozoa with high red fluorescence reflecting the percent of spermatozoa with abnormal chromatin

${ }^{2} \mathrm{SD}_{\alpha \mathrm{t}}=$ standard deviation calculated on the basis of the whole $\alpha_{\mathrm{t}}$ histogram.

Table 2

Effect of the quality of sperm chromatin on effectiveness of IVP in cattle (Einfluss der Spermaqualität auf die Effektivität der IVP beim Rind)

\begin{tabular}{|c|c|c|c|c|c|c|}
\hline \multirow{2}{*}{$\begin{array}{l}\text { No of } \\
\text { group }\end{array}$} & \multirow{2}{*}{$\begin{array}{l}\text { No of } \\
\text { bulls }\end{array}$} & \multirow{2}{*}{$\begin{array}{c}\operatorname{COMP}_{\alpha t}^{1} \pm \\
\operatorname{SD}_{\alpha \mathrm{t}}^{2}\end{array}$} & \multirow{2}{*}{$\begin{array}{c}\text { No of } \\
\text { oocytes } \\
\text { used }\end{array}$} & \multirow{2}{*}{$\begin{array}{c}\text { Cleaved embryos } \\
\text { No }(\%)\end{array}$} & \multicolumn{2}{|c|}{ No $(\%)$ of blastocysts } \\
\hline & & & & & Total & Hatched \\
\hline 1 & 3 & $0.82 \pm 6.82$ & 1150 & $960(83.5)^{\mathrm{a}}$ & $266(23.1)^{\mathrm{a}}$ & $95(35.7)^{\mathrm{a}}$ \\
\hline 2 & 6 & $1.70 \pm 15.82$ & 773 & $527(68.2)^{b}$ & $137(17.7)^{b}$ & $76(55.5)^{b}$ \\
\hline 3 & 3 & $18.16 \pm 53.59$ & 501 & $257(51.3)^{\mathrm{c}}$ & $61(12.2)^{\mathrm{c}}$ & $33(54.1)^{b}$ \\
\hline
\end{tabular}

${ }^{1} \mathrm{COMP}_{\alpha \mathrm{t}}=\%$ of spermatozoa with high red fluorescence reflecting the percent of spermatozoa with abnormal chromatin

${ }^{2} \mathrm{SD}_{\alpha \mathrm{t}}=$ standard deviation calculated on the basis of the whole $\alpha_{\mathrm{t}}$ histogram.

${ }^{\mathrm{a}-\mathrm{c}}$ Values within column with different letters significantly differ $\left(\chi^{2}\right.$ test; $\left.\mathrm{P}<0.01\right)$.

The comparison of the fertilizability of frozen-thawed sperm with minimal, low and high percentages of spermatozoa with abnormal chromatin indicated that significantly more $(\mathrm{P}<0.01)$ oocytes cleaved and reached the blastocyst stage when for the in vitro fertilization was used sperm showing the minimal percentage of defective chromatin structure (Table 2). However, the quality of sperm chromatin structure has not affected hatching ability of produced blastocysts (Table 2). Moreover, it was observed that even using sperm (of the bull no. 8) with the highest content of damaged chromatin (23.83) it was possible to obtain $10.1 \%$ of the blastocysts (Table 1 ).

\section{Discussion}

The previous experiments (EYESTONE and FIRST, 1989; KATSKA et al., 1994, 1996) have shown that in terms of factors affecting the outcome of IVP bull variability has appeared to be the main source of differentiation in the efficiency of this technology. In trying to find the explanation for the differentiated susceptibility of 
sperm of individual bulls to in vitro capacitation, which consequently reflected differences in their contribution to both fertilization and embryonic development, we have suggested that these differences may be caused by the defective chromatin structure. Therefore we conducted a comprehensive study that simultaneously compared quality of chromatin structure and the efficiency of IVP using frozenthawed sperm of several bulls showing similar morphological parameters of sperm.

Both the results of cytometric analysis of chromatin structure and efficiency of IVP with the same sperm samples showed a large variation among ejaculates of different bulls. It is well known that the outcome of IVP can be affected by several factors. Besides already mentioned bull effect a second factor affecting IVP success rate is the cumulus oocyte complex (GALLI et al., 2003; LONERGAN et al., 2003). In fact, even a homogenous population of oocytes with a cumulus cell mass as similar as possible cannot guarantee the same developmental competence; therefore, cow effect on IVP results is also considered (LONERGAN et al., 2003). It seems that several replications of IVP with reasonable amount of oocytes allow eliminating, at least to some degree, these ranges in oocyte developmental competence. In trying to reduce as much as possible the cow effect on IVP results we have decided to combine results for sperm with minimal, low and high percentages of defected chromatin structure.

The summarized data presented in Table 2 clearly shows the effect of quality of bull sperm chromatin structure on the in vitro embryo production efficiency. When sperm with minimal content of damaged chromatin was used for IVF, the highest efficiency of in vitro produced blastocysts was observed.

The earlier experiment of SAILER et al. (1996) has established the correlation between chromatin defects and as many as 16 morphometric parameters of bull spermatozoa. However, it was suggested that some spermatozoa with defective chromatin might be morphologically normal and even capable of penetrating an oocyte (GORCZYCA et al., 1993; DARZYNKIEWICZ et al., 1997). Our present study seems to support this hypothesis. All semen samples were to some extent uniform with respect to motility, survival time and capacity for freezing. Therefore, morphological characteristics have similar effect on fertility of all tested semen samples and chromatin structure is rather independent of other semen parameters. This evidence also shows that chromatin structure defects of spermatozoa cannot be observed microscopically, but should be evaluated using flow cytometric analysis after induced denaturation.

Comparing the effect of sperm with relatively higher (3.55\%-5.09\%) and lower $(2.03 \%-2.61 \%) \mathrm{COMP}_{\alpha \mathrm{t}}$ on the numbers of embryos and non-fertilized eggs Smorag et al. (2000) observed a correlation between sperm chromatin damages in the semen used for AI and the numbers of morphologically normal embryos and non-fertilized eggs that were collected from superovulated donors. The SCSA method, according these authors, is useful for the selection of semen samples with the greatest potential for recovering fertilized, normal embryos from superovulated donor cows.

Interestingly, in our experiment it was observed that even sperm with the high content of damaged chromatin was capable of penetrating and fertilizing the oocytes and consequently $10 \%$ of blastocysts was produced. However, it has been found (LARSON et al., 2000) that as much as $27 \%$ of spermatozoa with abnormal chromatin in human semen resulted in no pregnancies following assisted reproduction. 
Therefore it would be very interesting to find a similar "threshold" for bulls. However, for these purposes developmental competence of embryos should be determined after ET to synchronized recipients. It will identify the real effect of defective sperm rate on IVP embryo competence.

\section{References}

ASHWORTH, P.J.C.; HARRISON, R.A.P.; MILLER, N.G.A.; PLUMMER, J.M.; WATSON, P.F.:

Flow cytometric detection of bicarbonate-induced changes in lectin binding in boar and ram sperm populations. Mol.Reprod. Dev. 40 (1995), 164-176

BARANDI, Z.S.; SOLTI, L.; CSEH, S.; VARGA, Z.S.; MACHATY, Z.; VAJTA, G.:

Comparison of the in vitro fertilizing ability of sperm from endangered Hungarian Grey bulls. Anim.

Reprod. Sci. 31 (1993), 13-19

BOCHENEK, M.; SMORĄG, Z.; PILCH, J.:

Sperm chromatin structure assay of bulls qualified for artificial insemination. Theriogenology 56 (2001), 557-567

DARZYNKIEWICZ, Z.:

Probing nuclear chromatin by flow cytometry. In: Flow Cytometry and Sorting (1990), Melamed MR (ed), New York, Wiley-Liss, 315-340

DARZYNKIEWICZ, Z.; JUAN, G.; LI, X.; GORCZYCA, W.; MURAKAMI, T.; TRAGANOS, F.:

Cytometry in cell necrobiology: analysis of apoptosis and accidental cell death (necrosis). Cytometry 27 (1997), 1-20

EVENSON, D.P.:

Flow cytometric analysis of male germ cell quality. In: Methods In Cell Biology, Vol. 33 (1990), San Diego, Academic Press, 401-410

EYESTONE, W.H.; FIRST, N.L.:

Variation in bovine embryo development in vitro due to bulls. Theriogenology 31 (1989), 191 abstr.

FENICHEL, P.; HIS, B.L.; FARAHIFAR, D.; DONZEAU, M.; BARRIER-DELPECH, D.; YEH, J.G.:

Evaluation of the human sperm acrosome reaction using monoclonal antibody GB24 and a fluorescence-activated cell sorter. J. Reprod. Fertil. 87 (1989), 699-706

GALLI, C.; DUCHI, R.; CROTTI, G.; TURINI, P.; PONDERATO, N.; COLLEONI, S.; LAGUT, I.; LAZZARI,

G.: Bovine embryo technologies. Theriogenology 59 (2003), 599-616

GARNER, D.L.; ERICSSON, S.A.; THOMAS, C.A.; MARSHALL, C.E.: Interrelationships of flow cytometric measurements and classical seminal quality determinations with fertility of cryopreserved bull semen. Proc. $12^{\text {th }}$ Int. Congr. Anim. Reprod., Hague, 1 (1992), 467 abstr.

GILLES, M.; SEVERIN, U.; SCHAEFER, M.; GLATZEL, P.:

Biotesting of spermatozoa function for the use in in-vitro-systems. Arch. Tierz., Dummerstorf 44 (2001) Special Issue, 118-120

GARNER, D.L.; JOHNSON, L.A.; YUE, S.T.; ROTH, B.L.; HAUGLAND R.P.:

Dual DNA staining assessment of bovine sperm viability using SYBR14 and propidium iodide. J. Androl. 15 (1994), 620-629

GORCZYCA, W.; TRAGANOS, F.; JESIONOWSKA, H.; DARZYNKIEWICZ, Z.:

Presence of DNA strand breaks and increased sensitivity of DNA in situ to denaturation in abnormal human sperm cells. Analogy to apoptosis of somatic cells. Exp. Cell Res. 207 (1993), 202-205

GRAHAM, J.K.; KUNZE E.; HAMMERSTEDT, R.H.:

Analysis of sperm cell viability, acrosomal integrity and mitochondrial function using flow cytometry. Biol. Reprod. 43 (1990), 55-64

HILLERY, F.L.; PARRISH, J.J.; FIRST, N.L.:

Bull specific effect on fertilization and embryo development in vitro. Theriogenology 33 (1990), 249

KARABINUS, D.S.; EVENSON, D.P.; JOST, L.K.; BAER, R.K.; KAPROTH, M.T.:

Comparison of semen quality in young and mature Holstein bulls measured by light microscopy and flow cytometry. J. Dairy Sci. 73 (1990), 2364-2371

KARABINUS, D.S.; EVENSON, D.P.; KAPROTH, M.T.:

Effects of egg-yolk citrate and milk extenders on chromatin structure and viability of cryopreserved bull sperm. J. Dairy Sci. 74 (1991), 3836-3848

KĄTSKA, L.; RYŃSKA, B.:

Bull effect on developmental capacity of bovine in vitro matured and fertilized oocytes. In: M. Tischner and K.J. Scott (eds), Proc. First European Conference on Embryo Technology and Genetic Engineering in Cattle and Sheep Breeding, Kraków (1994), 215 
KĄTSKA, L.; RYŃSKA, B.; SMORĄG, Z.:

Effect of seminal plasma on the in vitro fertilizability of bull spermatozoa. Anim. Reprod. Sci. 44 (1996), 23-31

KĄTSKA, L.; RYŃSKA, B.; SMORĄG, Z.:

Developmental competence of bovine IVM/IVF oocytes under different co-culture conditions. J. Anim. Feed Sci. 7 (1998), 353-362

LARSON, K.L.; DEJONGE, C.J.; BARNES, A.M.; JOST, L.K.; EVENSON, D.P.:

Sperm chromatin structure assay parameters as predictors of failed pregnancy following assisted reproductive techniques. Human Reprod. 15 (2000), 1717-1722

LONERGAN, P.; RIZOS, D.; GUTIERREZ-ADAN, A.; FAIR, T.; BOLAND, M.P.:

Oocyte and embryo quality: effect of origin, culture conditions and gene expression patterns. Reprod. Domest. Anim. 38 (2003), 259-267

PARRISH, J.J.; SUSKO-PARRISH, J.L.; WINER, M.A.; FIRST, N.L.:

Capacitation of bull sperm by heparin. Biol. Reprod. 38 (1988), 1171-1180

RODRIGUEZ-MARTINEZ, H.:

Sperm function in cattle and pigs:morphological and functional aspects. Arch. Tierz., Dummerstorf 44 (2001), Special Issue, 118-120

SAILER, B.L.; JOST, L.K.; EVENSON, D.P.:

Bull sperm morphometry related to abnormal chromatin structure and fertility. Cytometry 24 (1996), 167-173

SMORĄG, Z.; BOCHENEK, M.; WOJDAN, Z.; SŁONIEWSKI, K.; REKLEWSKI, Z.:

The effect of sperm chromatin structure on quality of embryos derived from superovulated heifers. Theriogenology 53 (2000), 206 abstr.

UHLER, M.L.; LEUNG, A.; CHAN, S.Y.; SCHMID, I.; WANG, C.:

Assessment of human sperm acrosome reaction by flow cytometry: validation and evaluation of the method by fluorescence-activated cell sorting. Fertil. Steril. 60 (1993), 1076-1081

Received: 2004-06-03

Accepted: 2004-12-07

Corresponding author

Prof. Dr. habil. LUCYNA KĄTSKA-KSIAZŻKIEWICZ

National Research Institute of Animal Production, Department of Animal Reproduction

Biotechnology, Immuno- and Cytogenetics

32-083 Balice near Kraków, Poland

E-mail: 1katska@izoo.krakow.pl 